\title{
Modeling Fruit Growth of 'Triunfo' Pear Grown in North Espírito Santo State
}

\author{
Vinicius Soares de Oliveira ${ }^{1}$, Vinicius de Souza Oliveira ${ }^{2}$, Karina Tiemi Hassuda dos Santos ${ }^{1}$, \\ Gleyce Pereira Santos ${ }^{1}$, Lucas Moreira Borges Junior ${ }^{1}$, Adriel Lima Nascimento ${ }^{2}$, Rodrigo Amaro de Salles ${ }^{2}$, \\ Sara Dousseau Arantes ${ }^{3}$, Edney Leandro da Vitória ${ }^{1}$, Omar Schmildt ${ }^{1}$, Robson Prucoli Posse ${ }^{4}$, \\ Moisés Zucoloto ${ }^{2} \&$ Edilson Romais Schmildt ${ }^{1}$ \\ ${ }^{1}$ Federal University of Espírito Santo, São Mateus, ES, Brazil \\ ${ }^{2}$ Federal University of Espírito Santo, Alegre, ES, Brazil \\ 3 Capixaba Institute for Research, Technical Assistance and Rural Extension, Regional Center for Rural \\ Development, Brazil \\ ${ }^{4}$ Federal Institute of Espírito Santo-Campus Itapina, Colatina, Espírito Santo, Brazil \\ Correspondence: Vinicius de Souza Oliveira, Federal University of Espírito Santo, Alegre, ES, Brazil. E-mail: \\ souzaoliveiravini@gmail.com
}

Received: March 8, 2020

Accepted: April 14, $2020 \quad$ Online Published: May 15, 2020

doi:10.5539/jas.v12n6p153

URL: https://doi.org/10.5539/jas.v12n6p153

\begin{abstract}
The objective of this study was to obtain mathematical models to estimate non-destructively the fruit mass of pear cv. 'Triunfo'. To this end, 128 fruits from all developmental stages collected at three different times were used. Fruits were measured for maximum length (L), maximum width (W) and observed mass (OM). For the adjustment, with a sample of 100 fruits, the models first degree linear, quadratic and power were tested, in which the OM was used as the dependent variable in function of $\mathrm{L}$ and W. From a sample of 28 fruits, separated for this purpose the equations were validated. Thus, it indicates an equation of the quadratic model represented by $\mathrm{EM}=36.020218-3.067232(\mathrm{~W})+0.082568(\mathrm{~W})^{2}$ using from the measurement of the largest fruit width $(\mathrm{W})$, as the most accurate to estimate the fruit mass of pear cv. 'Triunfo'.
\end{abstract}

Keywords: Pyrus communis L., non-destructive method, mathematical equations

\section{Introduction}

Belonging to the Rosaceae family, the pear (Pyrus communis L.) is the third most consumed temperate fruit in Brazil, with a production of 22,108 tonnes in 2017, with standing out the states of Rio Grande do Sul $(12,839 \mathrm{t})$, Santa Catarina (7,334 t), Paraná (1,341 t), São Paulo (300 t) and Minas Gerais (294 t) (IBGE, 2018). However, Brazil is unable to meet all the demand for supplying the national market, making it necessary to import a large part of the fruits consumed in the country (Oliveira et al., 2015). In part, the insufficient Brazilian production is linked to the lack of studies that seek to adapt new cultivars to regions with productive potential (Fachinello et al., 2011).

The pear tree is a plant of the temperate climate, which requires temperatures of $7.2{ }^{\circ} \mathrm{C}$ or less for a good vegetative and reproductive development (Oliveira et al., 2015). There are cultivars that require a high amount of cold hours $(700$ to $1200 \mathrm{~h}$ ) and there are those with less accumulated cold hours (less than $500 \mathrm{~h}$ ), which are more interesting for Brazilian producers (Nakasu \& Faoro, 2003).

Among the cultivars with little demand for accumulated cold hours, we can highlight the cv. 'Triunfo' which presents large fruits, with an oblong shape, thick film, green color, and peel scores, the pulp is firm, granulated, with an acidic sweet flavor and of regular quality (Nakasu et al., 2007). This cultivar has been shown to have great potential for the tropical and subtropical regions of Brazil (Bettiol Neto et al., 2014; Oliveira et al., 2015). However, there are few studies that prove its productive effectiveness (Bettiol Neto et al., 2014).

In relation to the knowledge of the fruit growth patterns, this practice facilitates the decision making of the cultural treatments, allowing the adoption of appropriate techniques in the management, harvesting and post-harvesting of the fruits, in addition to indicating maturation and quality (Muianga et al., 2016). 
In this context, modeling to estimate fruit growth has been shown to be an important tool in helping researchers and producers. This method relates characteristics such as width, length, diameter and/or height as the fruit mass allowing, through simple equations, to estimate the fruit mass without the need for its destruction (Jorquera-Fontena et al., 2017).

Thus, the aim of this study was to obtain, test and calibrate mathematical models to estimate non-destructively the mass of pear fruits cultivar 'Triunfo' from their length and width.

\section{Method}

The present work was carried out with pear fruits cv. 'Triunfo', collected from Boa Vista farm, in the municipality of Montanha, North of the State of Espírito Santo, Brazil, located with the geographical coordinates of $18^{\circ} 07^{\prime} 48^{\prime \prime}$ South Latitude and $40^{\circ} 13^{\prime} 08^{\prime \prime}$ East Longitude. The region's climate according to the Köppen classification is Tropical Aw, with dry winter and summer rain (Alvares et al., 2014).

The orchard is made up of 300 trees, planted in September 2014. For irrigation, a system located by microjet was used with a flow rate of $20 \mathrm{~L} / \mathrm{h}$, and a watering shift of $1 \mathrm{~h}$ per day. Fertilization was done with organic fertilizer Minho Fértil ${ }^{\circledR}$.

128 fruits were collected from all stages of development (Figure 1) in three different seasons: September 2018; January 2019 and March 2019. The fruits were packaged and transported to the laboratory where they were measured at maximum length (L) and maximum width (W) (Figure 2), as a digital caliper (Fowler ${ }^{(B)}$ ), in millimeters. The observed mass (OM, in $\mathrm{g}$ ) of each fruit was also obtained with an electronic precision scale $\left(\right.$ MARTE $\left.^{\circledR}\right)$.
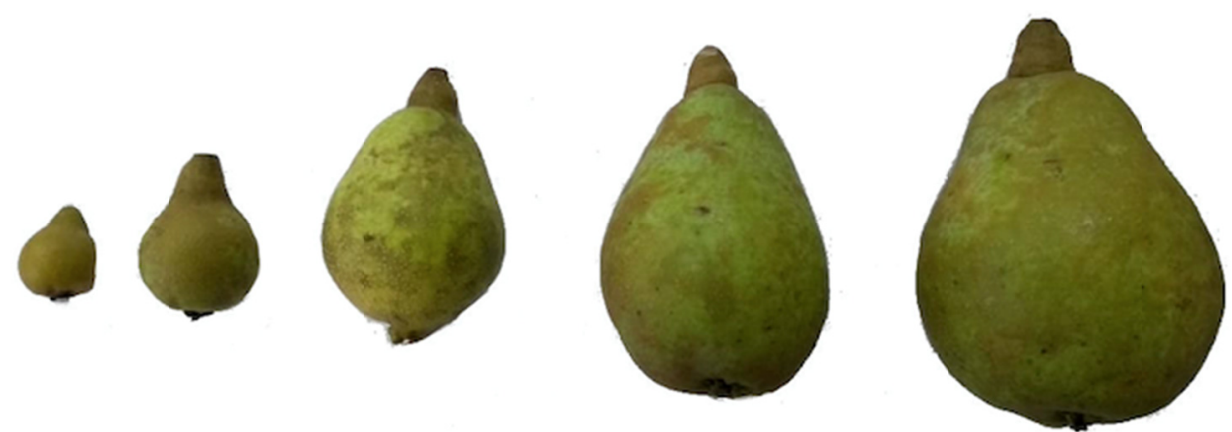

Figure 1. Different stages of development of pear fruits of cv. 'Triunfo' used for modeling

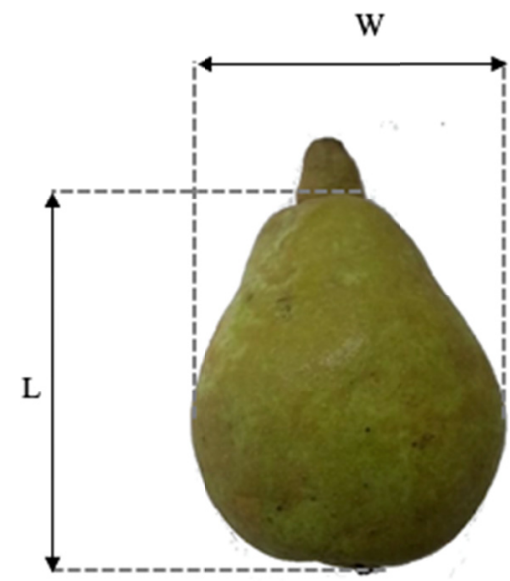

Figure 2. Representation of the length (L) and width (W) measures of pear fruits of cv. 'Triunfo'

To estimate the equations, 100 fruits were used and the first degree linear model represented by $E M=\widehat{\beta}_{0}+\widehat{\beta}_{1} \mathrm{x}$, quadratic represented by $E M=\widehat{\beta}_{0}+\widehat{\beta}_{1} x+\widehat{\beta}_{2} x^{2}$ and power represented by $E M=\widehat{\beta}_{0} x{ }_{1}$, was tested, in which OM was used as a dependent variable in function of $\mathrm{L}$ and $\mathrm{W}$ as an independent variable. Six models of equations were obtained to estimate the mass of pear cv. 'Triunfo' and its respective coefficients of determination $\left(\mathrm{R}^{2}\right)$. 
The validation was done based on 28 fruits, where the values of $\mathrm{L}$ and $\mathrm{W}$ were replaced in the proposed equations for modeling, thus obtaining the estimated mass (EM, in g). A simple linear regression model $\left(\mathrm{EM}=\widehat{\beta}_{0}+\widehat{\beta}_{1} \mathrm{x}\right)$ was fitted for each model, where EM was the dependent variable as a function of $\mathrm{OM}$ as an independent variable. For each of the simple regression adjustments, the hypotheses $\mathrm{H}_{0}: \widehat{\beta}_{0}=0$ versus $\mathrm{H}_{\mathrm{a}}: \widehat{\beta}_{0} \neq 0$ and H0: $\widehat{\beta}_{1}=1$ versus Ha: $\widehat{\beta}_{1} \neq 1$ were tested, using the Student's $\mathrm{t}$ test at $5 \%$ probability. Also determined for all equations the mean absolute error (MAE), by the expression: $\mathrm{MAE}=\frac{\sum_{\mathrm{i}=1}^{\mathrm{n}}|\mathrm{EM}-\mathrm{OM}|}{\mathrm{n}}$, the root of the root mean square error (RMSE) by the expression: RMSE $=\sqrt{\frac{\sum_{\mathrm{i}=1}^{\mathrm{n}}(\mathrm{EM}-\mathrm{OM})^{2}}{\mathrm{n}}}$ and the Willmott index (d) (Willmott, 1981) by the expression: $\mathrm{d}=1-\left[\frac{\sum_{\mathrm{i}=1}^{\mathrm{n}}(\mathrm{EM}-\mathrm{OM})^{2}}{\sum_{\mathrm{i}=1}^{\mathrm{n}}(|\mathrm{EM}-\overline{\mathrm{OM}}|+|\mathrm{OM}-\overline{\mathrm{OM}}|)^{2}}\right]$. Where, EM are the estimated mass values; OM are the values of the observed mass; $\overline{\mathrm{OM}}$ is the average of the observed mass values; $n$ is the number of fruits used in the validation $(\mathrm{n}=28)$.

The best equation was defined by the following criteria: linear coefficient $\left(\widehat{\beta}_{0}\right)$ not different from zero; slope $\left(\widehat{\beta}_{1}\right)$ not different from one; MAE and RMSE closer to zero, and Willmott's d index (Willmott, 1981) closer to one. Statistical analyzes were performed with the aid of the R software (R Core Team, 2018), using the data package ExpDes.pt version 1.2 (Ferreira et al., 2018).

\section{Results and Discussion}

The equations resulting from the measures of the length and width of the fruits are shown in Table 1. The width, in general, presented a greater relationship with the mass of the fruits in all the models studied. The best adjustment in relation to the width may be associated with the piriform characteristic of the fruits, where there is a greater accumulation of mass in the medial-basal region, favoring the relationship between these characteristics. However, the quadratic and power model equations showed coefficient of variation values above 0.90 , which according to Rojas-Lara et al. (2008) is indicative of a good correlation between the variables under study.

Table 1. First degree linear model equations, quadratic and power adjusted using the observed mass (OM) in function of length (L) and width (W) and coefficient of determination $\left(\mathrm{R}^{2}\right)$, to estimate the mass of pear fruits cv. 'Triunfo'

\begin{tabular}{lll}
\hline Model & Equation & $\mathrm{R}^{2}$ \\
\hline Linear & $\mathrm{EM}=-95.0410+2.8363(\mathrm{~L})$ & 0.8101 \\
Linear & $\mathrm{EM}=-101.1943+4.0731(\mathrm{~W})$ & 0.8538 \\
Quadratic & $\mathrm{EM}=21.843750-1.560683(\mathrm{~L})+0.036666(\mathrm{~L})^{2}$ & 0.8840 \\
Quadratic & $\mathrm{EM}=36.020218-3.067232(\mathrm{~W})+0.082568(\mathrm{~W})^{2}$ & 0.9474 \\
Power & $\mathrm{EM}=0.0013(\mathrm{~L})^{2.6342}$ & 0.8780 \\
Power & $\mathrm{EM}=0.0013(\mathrm{~W})^{2.8365}$ & 0.9472 \\
\hline
\end{tabular}

Based on the validation criteria (Table 2), only the quadratic model and the power model, obtained from the largest fruit width, had results not different from zero and not different from one by the Student's test $(\mathrm{p}<0.05)$ for the linear coefficients $\left(\widehat{\beta}_{0}\right)$ and slope $\left(\widehat{\beta}_{1}\right)$ respectively (Table 2 ). The non-significance of these parameters is an excellent indicator of the accuracy of these equations, since when the observed mass is zero, the mass estimated by the model will also be zero and as there is a gradual increase in the observed mass, the estimated mass will follow the same behavior. However, the quadratic model equation presented mean absolute error (MAE) and root mean square error (RMSE) values closer to zero and d index value closer to one, in addition, this equation had a value of determination coefficient $\left(\mathrm{R}^{2}\right)$ slightly higher than the power model equation, being the same equation with higher values of $R^{2}$ in the modeling adjustment, thus, this model was the one that best met the statistical criteria established in this study. 
Table 2. Linear coefficient $\left(\widehat{\beta}_{0}\right)$, slope $\left(\widehat{\beta}_{1}\right)$ of simple linear model equations and coefficient of determination $\left(\mathrm{R}^{2}\right)$, adjusted between the estimated mass (EM) by the length (L) and the width (W) in function of the observed mass $(\mathrm{OM})$, in addition to the mean absolute error (MAE), root mean square error (RMSE) and Willmott's d index obtained individually to estimate the mass of pear fruits cv. 'Triunfo'

\begin{tabular}{llllllll}
\hline Model & Variable & $\hat{\beta}_{0}$ & $\hat{\beta}_{1}$ & $\mathrm{R}^{2}$ & MAE & RMSE & $\mathrm{d}$ \\
\hline Linear & $\mathrm{L}$ & $19.8071^{*}$ & $0.6653^{*}$ & 0.8807 & 17.6950 & 20.8103 & 0.9333 \\
Linear & $\mathrm{W}$ & $-1.6253^{*}$ & $0.8404^{*}$ & 0.8960 & 14.5610 & 16.5895 & 0.9471 \\
Quadratic & $\mathrm{L}$ & $13.8863^{*}$ & $0.8007^{*}$ & 0.8621 & 12.9459 & 15.9064 & 0.9513 \\
Quadratic & $\mathrm{W}$ & $-2.3632 \mathrm{~ns}$ & $1.0053^{\text {ns }}$ & 0.9534 & 5.4531 & 7.5983 & 0.9868 \\
Power & $\mathrm{L}$ & $11.7411^{*}$ & $0.8017^{*}$ & 0.8668 & 11.3522 & 14.9284 & 0.9569 \\
Power & $\mathrm{W}$ & $-5.2825^{\text {ns }}$ & $1.0745^{\text {ns }}$ & 0.9530 & 5.8751 & 7.8649 & 0.9849 \\
\hline
\end{tabular}

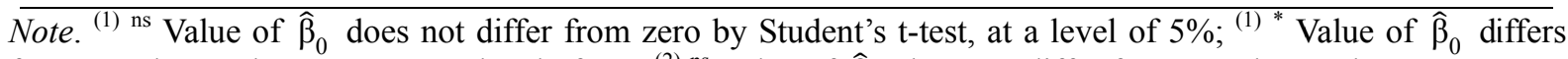
from zero by Student's t-test, at a level of 5\%; ${ }^{(2)}$ ns Value of $\hat{\beta}_{1}$ does not differ from one, by Student's t-test, at a level of $5 \% ;{ }^{(2)}{ }^{*}$ Value of $\widehat{\beta}_{1}$ differs from one, by Student's t-test, at a level of $5 \%$.

In several countries, characteristics such as pulp firmness, soluble solids, color and amount of starch are used as parameters to determine the ripeness of pear fruit, however, in places with moderate winter, no parameters are found to indicate the maturation of these fruits, considering the days between flowering and the characteristic harvest, which can be variable according to climatic conditions (Bettiol Neto et al., 2014).

As it is a fruit that does not reach the stage of ripening outside the plant, the pear needs new technology to assist the producer, since there are great losses of this fruit in the post-harvest. In this way, mathematical modeling of the pattern of fruit growth can facilitate crop management. This type of model has the function of helping in decision-making in relation to crop treatment, especially in the harvest, estimating exactly the fruit growth habit (Cunha \& Volpe, 2011).

Thus, we indicate the quadratic model equation represented by $\mathrm{EM}=36.020218-3.067232(\mathrm{~W})+0.082568(\mathrm{~W})^{2}$ (Figure 3) obtained from the largest width (W) measure of the fruits as the most accurate to estimate the mass of pear fruits cv. 'Triunfo'. It should be noted that this model should be used in edaphoclimatic situations similar to those mentioned in this study. Always respecting the limits of the values used for the adjustment (Levini et al., 2017). Another important fact to be taken into account is that the fruits developed from the process of parthenocarpy, thus, the seeds are absent from these fruits and may directly influence its shape. If the researcher or producer wishes to use these equations in other types of conditions, different from those of this study, these equations must be calibrated again using appropriate statistical criteria, in order not to generate an imprecise estimate of the fruit mass.

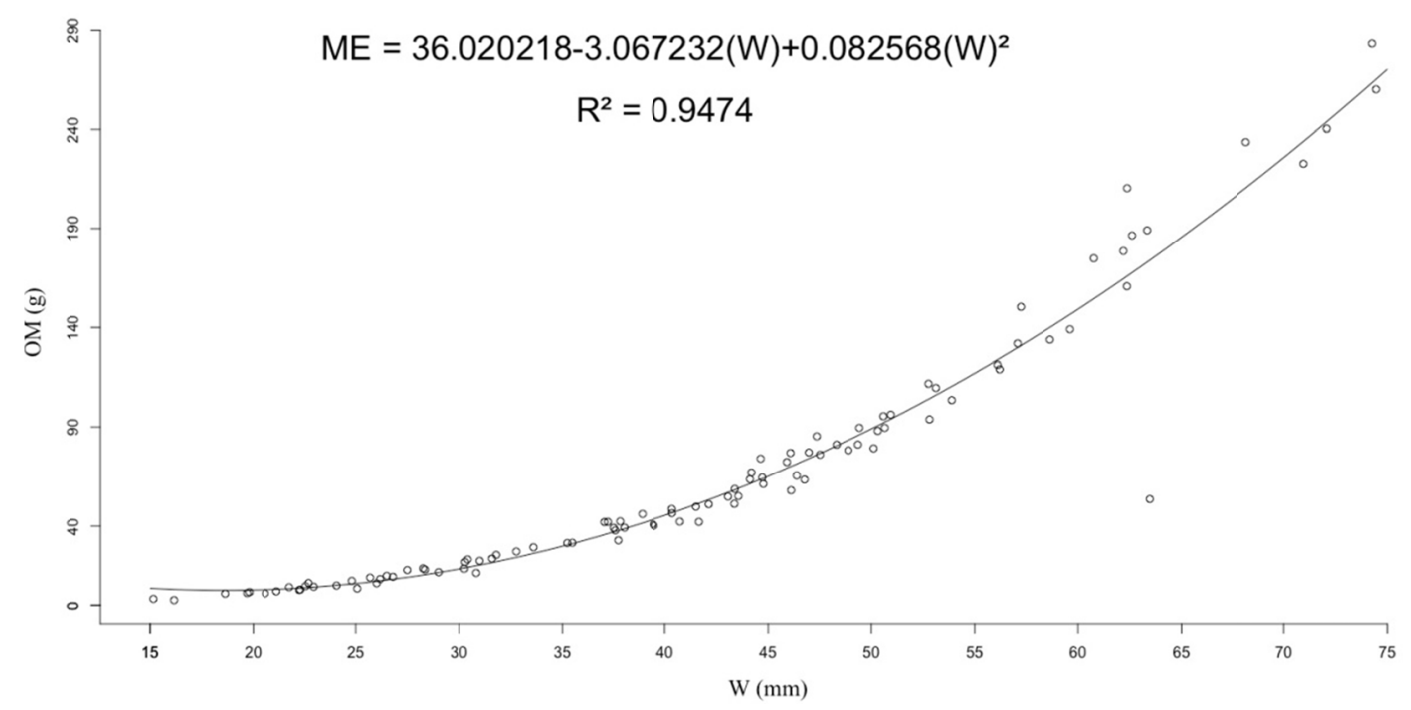

Figure 3. Quadratic model equations adjusted using the observed mass (OM) in function of the largest width (W) and determination coefficient $\left(\mathrm{R}^{2}\right)$ to estimate the mass of pear fruits of cv. 'Triunfo' 


\section{Conclusion}

The pear fruits of the cultivar 'Triunfo', can have their mass estimated through their greater width (W) by the quadratic model equation represented by $\mathrm{EM}=36.020218-3.067232(\mathrm{~W})+0.082568(\mathrm{~W})^{2}$, in a simple, precise and non-destructive way.

\section{Acknowledgements}

CNPq, CAPES and FAPES for financial support.

\section{References}

Alvares, C. A., Stape, J. L., Sentelhas, P. C., Gonçalves, J. L. M., \& Sparovek, G. (2014). Köppen's climate classification map for Brazil. Meteorologische Zeitschrift, 22(6), 711-728. https://doi.org/10.1127/09412948/2013/0507

Bettiol Neto, J. E., Chagas, E. A., Sanches, J., Pio, R., Antoniali, S., \& Cia, P. (2014). Production and postharvest quality of pear tree cultivars in subtropical conditions at eastern of São Paulo state, Brazil. Ciências Rural, 44(10), 1740-1746. https://doi.org/10.1590/0103-8478cr20131574

Cunha, A. R., \& Volpe, C. A. (2011). Growth curves of coffee fruits Obatã IAC 1669-20 in different alignments planting. Semina: Ciências Agrárias, 32(1), 49-62. https://doi.org/10.5433/1679-0359.2011v32n1p49

Fachinello, J. C., Pasa, M. S., Schmtiz, J. D., \& Betemps, D. L. (2011). Situation and perspectives of temperate fruit crops in Brazil. Revista Brasileira de Fruticultura, 33, 109-120. https://doi.org/10.1590/S010029452011000500014

Ferreira, E. B., Cavalcanti, P. P., \& Nogueira, D. A. (2018). Package 'ExpDes.pt'.

IBGE. (2018). Produção Agrícola Municipal. Retrieved April 20, 2019, from http://sidra.ibge.gov.br

Jorquera-Fontena, E., Génard, M., Ribera-Fonseca, A., \& Franck, N. A. (2017). simple allometric model for estimating blueberry fruit weight from diameter measurements. Scientia Horticulturae, 219, 131-134. https://doi.org/10.1016/j.scienta.2017.03.009

Levine, D. M., Stephan, D. F., \& Szabat, K. A. (2017). Statistics for Managers Using Microsoft ${ }^{\circledR}$ Excel: Global Edition (8th ed., p. 728). London: Pearson.

Muianga, C. A., Muniz, J. A., Nascimento, M. A., Fernandes, T. J., \& Savian, T. V. (2016). Description of the growth curve of cashew fruits in nonlinear models. Revista Brasileira de Fruticultura, 38(1), 22-32. https://doi.org/10.1590/0100-2945-295/14

Nakasu, B. H., \& Faoro, I. D. (2003). Cultivares. In B. H. Nakasu, A. C. Quezada, \& F. G. Herter (Eds.), Pêra: Produção (Cap. 5, pp. 29-36). Pelotas: Embrapa Clima temperado; Brasília: Embrapa Informação Tecnológica.

Nakasu, B. H., Herter, F. G., Camelatto, D., Reisser Júnior, C., Fortes, J. F., Castro, L. A. S., ... Simões, F. (2007). A Cultura da pêra. Embrapa Clima Temperado (p. 58). Brasília, DF: Embrapa Informação Tecnológica.

Oliveira, I. V. M., Lopes, P. R. C., \& Silva-Matos, R. R. S. (2015). Phenology evaluation of 'triumph' pear trees grown in semi-arid climate in the northeast Brazil in 2012 season. Revista Brasileira de Fruticultura, 37(1), 261-266. https://doi.org/10.1590/0100-2945-007/14

R Core Team. (2018). R: A language and environment for statistical computing. Vienna: R Foundation for Statistical Computing, Vienna, Austria.

Rojas-Lara, P. C., Pérez-Grajales, M., Colinas-León, M. T. B., Sahagún-Castellanos, J., \& Avitia-García, E. (2008). Modelos matemáticos para estimar el crecimiento del fruto de chile manzano (Capsicum pubescens RYP). Revista Chapingo Serie Horticultura, 14(3), 289-294. https://doi.org/10.5154/r.rchsh.2007.08.041

Willmott, C. J. (1981). On the validation of models. Physical Geography, 2(2), 184-194. https://doi.org/10.1080/ 02723646.1981 .10642213

\section{Copyrights}

Copyright for this article is retained by the author(s), with first publication rights granted to the journal.

This is an open-access article distributed under the terms and conditions of the Creative Commons Attribution license (http://creativecommons.org/licenses/by/4.0/). 